2 Swartz MN, Kunz LJ. Pasteurella multocida infection in man: report of 2 cases. N Engl f Med 1959;261:888.

${ }^{3}$ Schmidt EC, Previtt LV, Koch ML. Pulmonary abscess with empyema caused by Pasteurella multocida. Report on a fatal case. Am $\mathcal{J}$ Clin Pathol $1970 ; \mathbf{5 4}: 733$.

4 Itoh M, Tierno PMJ, Milstoc M, Berger AR. A unique outbreak of Pasteurella multocida in a chronic disease hospital. Am $\mathcal{F}$ Public Health $1980 ; 70(11): 1170-3$

${ }^{5}$ Hubert WT, Rosen MN. Pasteurella multocida infection. II. Pasteurella multocida infection in man unrelated to animal bite. Am $\mathcal{F}$ Public Health $1970 ; 60: 1 / 09$

(Accepted 29 March 1983)

Cuckfield Hospital, Haywards Heath, Sussex RH17 5HQ

C P SINGH, MB, MRCP, medical registrar

J R R SPURRELL, FRCP, consultant physician

Correspondence to: Dr C P Singh.

\section{Cimetidine and metoclopramide in oesophageal reflux disease}

Although cimetidine is effective in oesophageal reflux disease, it is not as consistently useful as in peptic ulceration. Metoclopramide increases lower oesophageal sphincter pressure in normal subjects ${ }^{2}$ and patients with reflux ${ }^{3}$ and speeds gastric emptying. ${ }^{4}$ These properties together with the acid lowering effect of cimetidine appeared to provide a sound rationale for combination therapy.

\section{Patients, methods, and results}

Seventy six patients with symptoms of oesophageal reflux entered a multicentre study. They were allocated at random to 12 weeks' treatment with cimetidine $400 \mathrm{mg}$ three times daily with meals and at bedtime, with or without metoclopramide $10 \mathrm{mg}$ three times daily with meals. All patients were supplied with Rennies as required for symptomatic relief. The double dummy technique was used to ensure that the study was double blind. Symptomatic and endoscopic assessment was carried out at the start of the study, symptoms were reassessed at $2,4,8$, and 12 weeks, and a further endoscopy performed after 12 weeks. Grading, according to the endoscopic appearance of the oesophageal mucosa, was as follows: $0=$ normal, $1=$ friability, $2=$ discrete lesions (erosions or multiple superficial ulcers), 3 - confluent and longitudinal lesions, 4 circinate ulceration with or without complications. Endoscopic improve- ment was defined as a decrease of two grades or more at the second endoscopy compared with the first. Differences between the two treatments were analysed by $\gamma^{2}$ tests and $p$ accepted as significant at the 5\% level.

Three patients were excluded from the analysis for deviating from the protocol; of the remainder, 40 received cimetidine alone and 33 the combination. The groups were well matched for age, sex, duration of disease, smoking, and alcohol consumption. The cimetidine group, however, contained significantly more patients with stenosis $(6 v 0, \mathrm{p}<0 \cdot 05)$. The two treatments did not differ in their relief of symptoms or effect on antacid consumption, although there was a non-significant trend towards decreased antacid consumption in patients taking the combination. The rapid relief of heartburn is illustrated in the figure, some two thirds of the patients becoming symptom free within the first week. Eighteen of the 33 patients receiving cimetidine $(55 \%)$ had healed or improved oesophagitis at the end of the trial compared with eight of $19(42 \%)$ taking the combination (not significant).

A total of 32 adverse reactions were reported in 22 of the patients receiving the combination, while 16 patients receiving cimetidine alone reported 22 adverse events. Of these patients, 11 receiving the combination were withdrawn compared with three taking cimetidine $(p<0.01)$. Reasons for withdrawal of the 11 patients in the combination treatment group were vomiting and dizziness; somnolence (two cases); lethargy; nervousness and clumsiness; diarrhoea and lethargy; lethargy and depression; weakness, lethargy, and exhaustion; feeling of choking; "thick" speech and strange bodily sensation; and water brash and worsening of the stricture. The three patients in the cimetidine group were withdrawn complaining of epigastric pain, depression, and drowsiness and vomiting, respectively.

\section{Comment}

Although the effect on symptoms was comparable, the combination of metoclopramide and cimetidine appeared less effective in this study in producing endoscopic improvement and healing than cimetidine alone, although this difference did not reach statistical significance. A possible explanation might be that metoclopramide reduced the bioavailability of cimetidine. ${ }^{5}$ In our study adverse effects were certainly more common in patients receiving the combination and severe enough to necessitate withdrawal in one third. The results therefore suggest that, despite the plausible pharmacological rationale, there is no clinical advantage in coprescribing cimetidine and metoclopramide for oesophageal acid reflux disease.

We are grateful to Smith Kline and French Laboratories for supplies of cimetidine and financial support and to Beecham Laboratories for supplies of metoclopramide.

' Behar J, Brand DL, Brown FC, et al. Cimetidine in the treatment of symptomatic gastroesophageal reflux. Gastroenterology 1978;74:441-8.

2 Wallin L, Boesby S, Madsen T. Effect of metoclopramide on oesophageal peristalsis and gastro-oesophageal sphincter pressure. A study in normal subjects. Scand $\mathcal{F}$ Gastroenterol 1979;14:923-7.

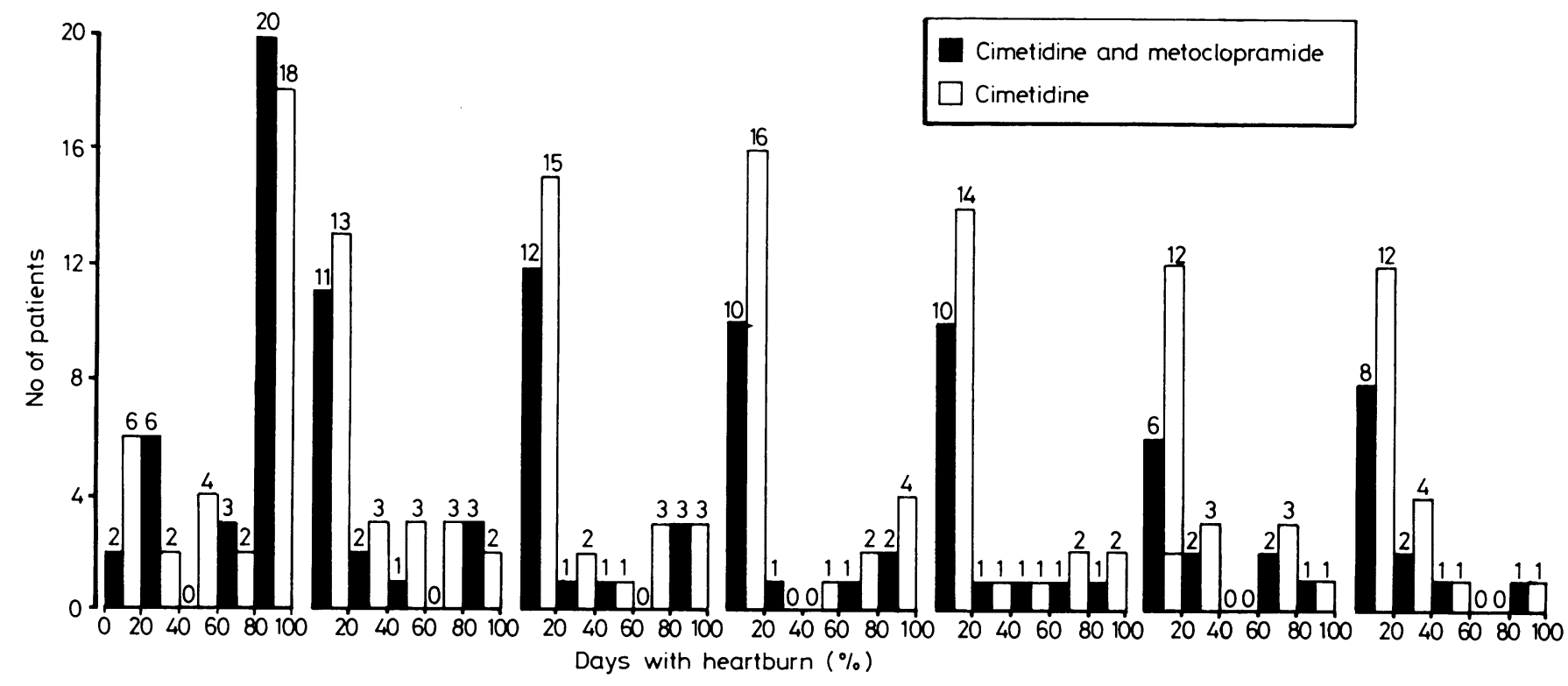

$\longmapsto$ Pretrial $\longrightarrow$ Weeks 1and $2 \dashv \vdash$ Weeks 3 and $4 \longrightarrow \vdash$ Weeks 5 and $6 \longrightarrow \vdash$ Weeks 7 and $8 \longrightarrow \vdash$ Weeks 9 and $10 \longrightarrow \vdash$ Weeks 11 and $12 \dashv$

Percentage of days with hearthurn in two week intervals. 
${ }^{3}$ McCallum RW, Kline MM, Curry N, Sturdevant RAL. Comparative efforts of metoclopramide and bethanechol on lower esophageal sphincter pressure in reflux patients. Gastroenterology 1975;68:1114-8.

${ }^{4}$ McCallum RW, Berkowitz DM. The frequency of delayed gastric emptying in patients with gastroesophageal reflux and its response to metoclopramide and bethanechol. Gastroenterology 1978;74:1135.

${ }^{5}$ Gugler R, Brand M, Somogyi A, et al. Impaired cimetidine absorption due to antacids and metoclopramide. Eur 7 Clin Pharmacol 1981;20:225-8.

(Accepted 29 March 1983)

Queen Elizabeth Hospital, Edgbaston, Birmingham B15 2TH

J G TEMPLE, CHM, FRCS, consultant surgeon

Sandwell District General Hospital, West Bromwich, West Midlands B71 4HJ

G V H BRADBY, MB, FRCP, consultant physician

Altnagelvin Hospital, Londonderry BT47 1JB, N Ireland

F O'CONNOR, MD, MRCP, consultant physician

K S PANESAR, FRCS, FRCSED, consultant surgeon

Craigavon Hospital, Craigavon, Co Armagh BT63 5QQ, N Ireland

T O MULLIGAN, FRCS, consultant surgeon

T J ROBINSON, MD, FRCP, consultant physician

Burnley General Hospital, Burnley BB10 3HP

D W WARD, MB, FRCP, consultant physician

Correspondence to: $\mathrm{Mr} \mathrm{J}$ G Temple.

\section{Serum ferritin concentration in Gaucher's disease}

The serum ferritin concentration is widely used as a measure of body iron stores but is inappropriately raised in liver disease and in chronic inflammatory and malignant diseases. We report finding raised serum ferritin concentrations in patients with Gaucher's disease.

\section{Patients, methods, and results}

We studied seven patients with type I Gaucher's disease. Serum ferritin was estimated by the immunoradiometric assay previously used in this laboratory. The proportion of glycosylated ferritin was estimated by the concanavalin A binding technique. Unsaturated transcobalamin II concentration was measured by radioactive vitamin $B_{12}$ binding and Quso G32 separation.' A standard desferrioxamine 24 hour urine excretion test was performed in two patients using an intramuscular dose of $10 \mathrm{mg}$ desferrioxamine $/ \mathrm{kg}$ body weight. Other haematological and biochemical measurements were by standard techniques. The table lists the clinical, haematological, and biochemical findings. None of the patients had received previous blood transfusions or, so far as we could ascertain, iron therapy.

Six of the seven patients showed raised serum ferritin concentrations. These bore no relation to the sex of the patient, size of the spleen or liver. blood count, extent of bone lesions, serum acid phosphatase activity, serum aspartate transaminase activity, or concentration of serum vitamin $B_{12}$ or unsaturated transcobalamin II. The transcobalamin II concentration was raised in all six patients studied. Interestingly, however, the two youngest patients showed the lowest serum ferritin values. The proportion of serum ferritin bound by concanavalin A, measured in five patients, ranged from $38 \%$ to $55 \%$ (within the normal range). The 24 hour urinary iron excretion after intramuscular desferrioxamine was normal in both patients tested (table).

\section{Comment}

Gaucher's disease is an inborn error of metabolism due to deficiency of a lysosomal enzyme, $\beta$-glucosidase, resulting in accumulation of glucocerebroside in large macrophages throughout the reticuloendothelial system. We found raised serum ferritin concentrations in six of seven patients with type I Gaucher's disease. This could not be attributed to iron overload as the urinary iron excretion after intramuscular desferrioxamine, estimated in two patients (cases 2 and 4 ) with a 10-fold increase in serum ferritin concentrations, was not increased. Other studies have found raised serum acid phosphatase activities and transcobalamin II concentrations in Gaucher's disease. Acid phosphatase is a lysosomal enzyme present in Gaucher's cells and transcobalamin II is synthesised by macrophages. ${ }^{3}$ Increased iron has been detected within the macrophages in Gaucher's disease. ${ }^{4}$ The iron is dispersed within the cells as individual micelles of ferritin." Probably raised serum ferritin concentrations in patients with Gaucher's disease result from excessive release of ferritin from the large macrophages (Gaucher's cells). Our results suggest that serum ferritin increases with age in Gaucher's disease, but a much larger study would be necessary to prove this. At all events, Gaucher's disease can be added to the list of conditions in which the serum ferritin value may be inappropriately high in relation to body iron stores.

${ }^{1}$ Jacob E, Wong K, Herbert V. A simple method for the separate measurements of transcobalamins I, II, II : normal ranges in serum and plasma in men and women. 7 Lab Clin Med 1977;89:1145-51.

2 Gilbert HS, Weinreb N. Increased circulating levels of transcobalamin II in Gaucher's disease. N Engl f Med 1976;195:1096-1101.

${ }^{3}$ Rachmilewitz B, Rachmilewitz M, Chaouat M, Schlesinger M. Production of TCII (vitamin $B_{12}$ transport protein) by mouse mononuclear phagocytes. Blood 1978;52:1089-97.

+ Lorber M. The occurrence of intracellular iron in Gaucher's disease. Ann Intern Med 1960;53:293-305.

${ }^{5}$ Lee RE, Balcerzak SP, Westerman MP. Gaucher's disease : a morphological study and measurement of iron metabolism. Am $\mathcal{f}$ Med $1967 ; \mathbf{4 2}$ : 891 .

(Accepted 22 March 1983)

Department of Haematology, Royal Free Hospital School of Medicine, London NW3 2QG

M A M MORGAN, BA, MRCP, registrar

A V HOFFBRAND, FRCP, FRCPATH, professor

M LAULICHT, senior medical laboratory scientific officer

W LUCK, medical laboratory scientific office

S KNOWLES, MRCP, MRCPATH, consultant

Correspondence to: Professor A V Hoffbrand.

\begin{tabular}{|c|c|c|c|c|c|c|c|}
\hline & \multicolumn{7}{|c|}{ Case No } \\
\hline & 1 & 2 & 3 & 4 & 5 & 6 & 7 \\
\hline Age (years) & 67 & 58 & 48 & 44 & 40 & 25 & 22 \\
\hline Sex & $\mathrm{F}$ & $\mathrm{F}$ & $\mathrm{M}$ & $\mathrm{F}$ & $\mathrm{F}$ & $\mathrm{M}$ & $\mathrm{F}$ \\
\hline Spleen (cm palpable) & 15 & Splenectomy & 0 & 0 & 3 & 3 & 3 \\
\hline Liver (cm palpable) & 0 & 0 & 0 & 0 & 2 & 2 & 4 \\
\hline $\begin{array}{l}\text { Bone lesions } \\
\text { Bate }\end{array}$ & ++ & ++ & - & + & - & + & + \\
\hline Haemoglobin $(\mathrm{g} / \mathrm{dl})$ & $11 \cdot 8$ & 13.9 & $12 \cdot 2$ & $11 \cdot 8$ & $11 \cdot 1$ & $12 \cdot 4$ & $12 \cdot 6$ \\
\hline White cell count $\left(\times 10^{\mu / 1}\right)$ & 50 & $11 \cdot 4$ & 4.7 & 6.9 & $4 \cdot 0$ & $3 \cdot 8$ & $5 \cdot 8$ \\
\hline Platelet count $\left(\times 10^{9} / 1\right)$ & 13 & 280 & 90 & 140 & 90 & 135 & 110 \\
\hline Serum aspartate transaminase (NR 5-40 U/1) & 17 & 17 & 24 & 44 & 48 & 64 & 26 \\
\hline Serum acid phosphatase (NR 0.5-3.0 KAU/dl) & $4 \cdot 9$ & $6 \cdot 2$ & $8 \cdot 7$ & $6 \cdot 3$ & $8 \cdot 9$ & $5 \cdot 1$ & 4.5 \\
\hline Vitamin $\mathrm{B}_{12}(\mathrm{NR} 160-925 \mathrm{ng} / \mathrm{l})$ & 160 & 220 & 300 & 320 & 400 & 400 & 440 \\
\hline Transcobalamin II (NR $500-900 \mathrm{ng} / \mathrm{l})$ & 1919 & 1393 & 1992 & 2529 & 2323 & ND & 2053 \\
\hline Ferritin (NR: M 39-340, F $14-148 \mu \mathrm{g} / \mathrm{l})$ & 1460 & 1500 & 1720 & 1200 & 1200 & 168 & 240 \\
\hline Concanavalin A ", binding & 55 & 39 & 42 & 38 & 52 & ND & ND \\
\hline 24 Hour urinary iron excretion after desferrioxamine (NR $\cdot 2 \cdot 2 \mathrm{mg} / 24 \mathrm{~h}$ ) & ND & $1 \cdot 04$ & $\mathrm{ND}$ & 0.59 & ND & ND & ND \\
\hline
\end{tabular}

